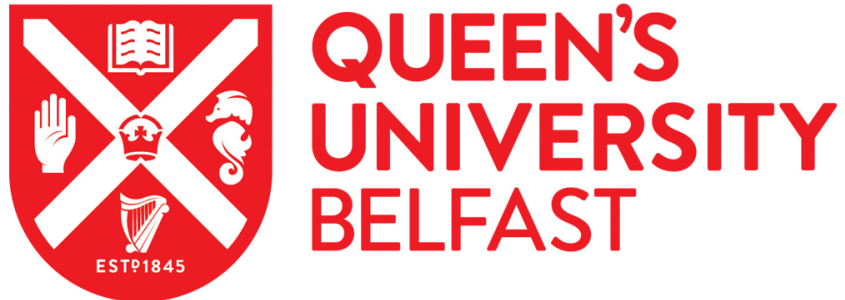

\section{Illustrations and Victorian Print Culture: A Case Study from the Expeditionary Narrative}

Livingstone, J. (2021). Illustrations and Victorian Print Culture: A Case Study from the Expeditionary Narrative. In Research Methods Primary Sources Adam Matthew Digital. https://doi.org/10.47594/RMPS_0093

\author{
Published in: \\ Research Methods Primary Sources
}

Document Version:

Peer reviewed version

Queen's University Belfast - Research Portal:

Link to publication record in Queen's University Belfast Research Portal

Publisher rights

Copyright 2021 Adam Matthew Digital.

\section{General rights}

Copyright for the publications made accessible via the Queen's University Belfast Research Portal is retained by the author(s) and / or other copyright owners and it is a condition of accessing these publications that users recognise and abide by the legal requirements associated with these rights.

Take down policy

The Research Portal is Queen's institutional repository that provides access to Queen's research output. Every effort has been made to ensure that content in the Research Portal does not infringe any person's rights, or applicable UK laws. If you discover content in the Research Portal that you believe breaches copyright or violates any law, please contact openaccess@qub.ac.uk. 


\section{Abstract}

Using an annotated proof of an engraving for David Livingstone's Missionary Travels, this case study models approaches that students can adopt when researching and analysing illustrations in published media. The case study begins with contextualisation, urging attention to the wider functions of illustrations in a particular literary genre - in this case, nineteenth-century expeditionary narratives - and to the specific function of a given illustration in a particular text. The case study then develops a close reading of the source image, "Reception of the Mission by Shinté". 
Following recent scholarship, it insists that such illustrations are not merely supplements that reproduce the printed word in visual form, but that they influence interpretation and bring their own meanings to the text. The close reading investigates the strategies of representation deployed in the image, disclosing the ways in which it mythologizes exploration and simplifies the complexity of intercultural encounter. This interpretation is extended by positing the dialogic nature of illustration; examining the interaction between the "Reception" and Livingstone's written description clarifies the ways in which the image filters the scene through familiar signifiers of the primitive and exotic. Finally, the case study demonstrates the critical results of book-historical perspectives. It reads the source image through the archive, using publishing records to unravel the collaborative processes and negotiations involved in producing an illustrated text. Through engagement with a single image, this case study employs interpretive methods that can be applied to illustrative materials in other literary forms. 


\section{Contextual information}

The term "illustration" refers to a particular visual genre: images whose purpose, broadly put, is the pictorial elucidation or representation of a text. Since illustrations occur in diverse literary forms from novels, to periodicals, to works of natural science - their examination can contribute to widely varying research projects. By providing insight into the representational practices used to portray particular subjects in particular periods, they serve as valuable sources for students of any historical field, including cultural history, literary studies, the history of science, historical geography and historical anthropology. Drawing on visual materials in such research contexts is no new practice, but it is only recently that illustration has itself become a primary focus of enquiry. Scholars, delineating what is now called "illustration studies", argue for the "validity of illustration as a distinct

object of study"; rather than conflating illustration with other visual forms, it should be understood as "a cultural and aesthetic practice that influences the process of reading" and that itself produces meanings. ${ }^{1}$ This turn towards illustration's complex meaning-making forms the critical context for the present case study. More specifically, it belongs in the context of scholarship now interrogating 
the ways that graphics in Victorian travel texts "visualized" non-European cultures and geographies for domestic audiences. ${ }^{2}$

The source for this case study is an annotated proof of an engraving, "Reception of the Mission by Shinté", that appeared in David Livingstone's Missionary Travels and Researches in South Africa (1857). ${ }^{3}$ Livingstone began his career as a missionary to the BaTswana in present-day South Africa and Botswana in 1841, but by the early 1850 s he developed aspirations to extend the missionary enterprise into central Africa. He turned to the Zambezi River, which he optimistically hoped would provide a "highway" to facilitate "legitimate commerce" between the coastal and central regions of the continent. To pioneer this pathway, Livingstone set out in 1853 on a journey that would lead him first to the Angolan coast, before subsequently taking him across the continent to Mozambique where he arrived in May 1856.

Livingstone's expedition was reported as the first successful transcontinental crossing by a European. Although he had been preceded by Afro-Portuguese traders, he was bestowed with public honours including the Royal Geographical Society's Gold Medal. As the book that would provide a detailed account of this journey, Missionary Travels aroused considerable expectation before it was published. John Murray, one of Britain's leading publishing houses, secured Livingstone with a lucrative book deal; as a travel specialist, with established connections to the Admiralty and Royal Geographical Society, the Murray house was well placed to produce a best-selling narrative. In the two years following publication, over 70,000 copies were sold.

Livingstone wrote his book in a period fascinated with global travel. From around 1800, the commercial popularity of travel books escalated rapidly; travel literature was the second-most published literary genre in Britain throughout the nineteenth century (trailing religious texts in the first half and fiction in the second). ${ }^{4}$ Like many other literary forms in the period, moreover, travel texts increasingly included visual material. Across the nineteenth-century, diverse techniques were used to produce images in print, like metal engraving and lithography, but at mid-century wood 
engraving was preferred; this method, which had developed at the end of the eighteenth century, involved carving on a wooden block to produce a raised design that could then be printed alongside type on a single page. ${ }^{5}$ Such efficiency, along with new technologies of mass reproduction, contributed to the rapid ascent of the illustrated book by allowing for the more cost-effective inclusion of pictorial matter. Publishers specializing in travel, like John Murray, capitalized on the possibilities that such transformations in print offered for texts designed to mediate distant regions to the home audience. Missionary Travels incorporated extensive visuals - mostly wood engravings - which no doubt contributed to its commercial success. These illustrations came from a variety of sources; many sketches were composed by Joseph Wolf and other artists, on the basis of Livingstone's descriptions, while a significant number were provided by other travellers, like the naval officer Captain Henry Need.

Livingstone's book, including its numerous pictures, fuelled the interest in central Africa that was intensifying at mid-century. It resonated powerfully with contemporary preoccupations - from the evangelical and humanitarian to the commercial and scientific - and incited missions, expeditions and colonial ventures to the extent that it became one of the nineteenth century's most influential works on Africa.

\section{Source analysis questions}

Having taken the initial steps and read/viewed the source(s) with the initial questions in mind - as well as reading the contextual information about the source - a more in-depth critical evaluation will now take place. 
1. What are the functions of illustration in the literary genre of nineteenth-century expeditionary narratives? Are there particular sorts of illustrations that tend to appear in these travel texts? Why might they be included?

2. Locate the source illustration in David Livingstone's Missionary Travels and read the surrounding passages. What purposes might the illustration serve in the context of Livingstone's book?

3. How does this illustration stage its scene? In what ways does it represent the encounter between European traveller and the local African community?

4. Examine the relationship between the illustration and Livingstone's textual description more closely. Does the image align with or depart from the events as represented in the narrative? Is there anything excluded from this illustration?

5. Since this source is a marked-up proof (i.e. the phase prior to publication), what differences are there between this engraving and the final published version? Are these variations significant?

6. Does the proof engraving tell us anything about its composition and production? What other sources of information are available about the illustrative processes involved in Missionary Travels? 


\section{Critical evaluation}

Here the critical evaluation of the source(s) is provided, and the questions raised in the preceding sections are addressed.

\section{Introduction}

David Livingstone's Missionary Travels is a richly illustrated expeditionary narrative. Following his celebrated transcontinental African expedition (1853-56) public anticipation was high, and his publisher - the prestigious house of John Murray - was prepared to make a significant investment in producing the volume. The first edition contained almost fifty illustrations including a lavish foldout frontispiece, a portrait of the author-explorer, and two elaborate maps prepared by the cartographer, John Arrowsmith. The illustration occupying this case study, "Reception of the Mission by Shinté", was thus part of an extensive range of illustrative material that made a major contribution to the impact of the book.

\section{Illustrating Travel}

Before addressing a particular illustration, the starting point is to ask the question: why was this narrative provided with illustrations? In the case of Missionary Travels, this involves investigating the function of the visual in the genre of expeditionary travel narratives published in the second half of the nineteenth century. The decades from 1850 to 1890 were the heyday of European exploration in

Africa. Fuelled by the geographical impetus to map the so-called "blank" spaces of the globe and by the interests of contemporary science (which intersected with humanitarian and commercial 
imperatives), the period witnessed a series of European journeys into the "unknown" regions of central Africa. Central to the contemporary protocols of scientific exploration was the expectation that the expedition would be followed by a published account that would disseminate geographical knowledge. As the historical geographer Felix Driver notes, "a journey of exploration only really counted as such when it was described by a narrative".${ }^{6}$ The illustrations that appeared in such texts participated in the task of bearing witness to the expedition; they had the responsibility, argues cultural historian Leila Koivunen, of "relaying the exploration of Africa" so that "[f]ar-away places, which had previously been accessible to only a handful of people, could now be seen and examined in almost every home". ${ }^{7}$ The illustrations then weren't simply decorative, but formed part of the expedition's scientific record on matters ranging from geography, to natural science and ethnography.

At the same time, the illustrations that circulated in expeditionary texts had wider cultural effects. "Visual representations", argues art historian Tim Barringer, "played a crucial role in forming an idea of Africa in the imagination of the Victorian public". ${ }^{8}$ Images with an ethnographic purpose were central to this process, for in their profound concern with racial difference they participated in what the anthropologist James Clifford calls "the invention, not the representation, of cultures". ${ }^{9}$ While travel illustrations sought to portray non-western geographies and peoples, they were also bound up with the public image and reputation of the European explorer. Particular graphics could of course portray this (generally male) figure in a host of ways, but it was common for mid-to-late nineteenth-century representations of African travel to draw heavily on the iconography of heroic masculinity. The inclusion of appropriate illustrative material also had the wider reputational function of enhancing the credibility of the published book and the traveller. Presented as direct evidence of regions visited, illustrations seemed to authenticate the explorer's witness and to consolidate the truthfulness of descriptions and claims made in print; by appearing to provide "visual 
proof" in support the narrative, they could help secure the perceived reliability of the text and the explorer's authority. ${ }^{10}$

Beyond the concerns that generally motivated the illustration of expeditionary narratives, more specific considerations underpinned the selection of any single image. For the researcher, it is critical to ask why an illustration has been included and to consider its function in a given narrative. While the visual material in Missionary Travels is widely varied, the present case study is an image that represents a particular moment in Livingstone's expedition. In a volume of around 700 pages, presenting numerous prospective scenes, the act of selecting an episode for illustration marks its significance in the narrative. "Reception of the Mission by Shinté" captures a meeting in January 1854 with a paramount chief of the southern Lunda, whose official title was the "Shinde" or "Ishindi" ${ }^{11}$ At this point, Livingstone was still in the early stages of the expedition that he hoped would pioneer an accessible trade route between the interior and the European world, having only recently passed into terrain that he had not previously visited. But to grasp the significance of the meeting with the Shinde, it is crucial to research the cultural context in which Livingstone was travelling. As Livingstone reports in Missionary Travels, in this expedition he was collaborating with the Makololo, a group that had migrated from the south in the early nineteenth-century and established a major state in the Zambezi valley around $1840 .{ }^{12}$ Scholarship on the Makololo empire indicates that the paramount, Sekeletu, was eager to consolidate his own trading network, which motived him to supply Livingstone with the crucial logistical and financial support for his exploratory venture. ${ }^{13}$ Since Livingstone was accompanied by a retinue supplied by Sekeletu, he would have been regarded in the surrounding regions as an emissary of the Makololo state.

On travelling into the homelands of the southern Lunda around a month after setting out from Sekeletu's town, Linyanti, Livingstone was departing from the area of Makololo ascendancy and entering a region where his reception was less assured. To develop the prospective trade route, Livingstone and his party would need to foster good relations with the southern Lunda. Soon after 
entering the region, Livingstone was escorted over a period of week to the Shinde's court; there, he was met with a major reception that involved formal introductions, musical performance, and shows of military strength. ${ }^{14}$ After several meetings over the following week, Livingstone departed from the Shinde assured of his friendship and support. ${ }^{15}$ The reception, then, was a defining moment in Livingstone's westward travel, as he moved between polities and secured his onward transit. ${ }^{16}$ It was an encounter that Livingstone and his publisher considered significant enough to memorialise in engraving and that would, in turn, gain importance in the narrative through its visual commemoration.

\section{Image and Text in Interaction}

Yet reading the image only as a signifier of important narrative events relies on a too straightforward account of the functions of illustration. As scholars in illustration studies argue, illustration has too often been regarded as simply "illustrative", as a supplement that is secondary to the printed narrative, or as a medium that merely reproduces the text in visual form. Illustrations, however, do not simply enact the dynamics of the printed word, but instead bring meaning to the text that can profoundly affect narrative interpretation. ${ }^{17}$ Researchers, therefore, must read illustrations as artefacts in themselves, attending to their modes of representation and meaningmaking. In the present case, "Reception of the Mission by Shinté" does more than highlight Livingstone's encounter with the southern Lunda paramount, but rather stages the interaction in particular ways. A notable feature is that the caravan described by Livingstone, which was supplied to him by Sekeletu, is obscured in the composition. ${ }^{18}$ The three men in the left-hand corner of the illustration are presumably retinue members, but since they are not in close proximity to Livingstone (positioned as they are, in the foreground) and since there is little to distinguish them from the Lunda spectators to their right, their identity remains ambiguous. Granting that the men are intended as expeditionary personnel, it is significant that they are so few. Livingstone reports that 
his Makololo-led caravan consisted of twenty-seven men, but the majority are made invisible here by the artist. With the retinue removed or at least reduced, the illustration heightens Livingstone's isolation, portraying him as a solitary traveller rather than one in transit as part of a collective. In doing so, the scene sustains one of the key myths of Victorian exploration; while European travellers in Africa were reliant on intermediaries like guides and interpreters, popular iconography cultivated explorers as individualistic heroes whose achievements were theirs alone ${ }^{19}$ In the case of Livingstone's transcontinental expedition this mythology is particularly misleading, since his authority was in no small part derived from his alliance with Sekeletu; he was travelling, in effect, as an "nduna" - or officer - of the Makololo paramount. ${ }^{20}$ By staging Livingstone as a lone European, the illustration conceals the larger political significance of a meeting between the Shinde's state and an envoy from the Makololo, and therefore simplifies the reception's complex intercultural dynamics.

Analysis of the Missionary Travels engraving can be extended by examining its interaction with the surrounding text more closely. A distinctive feature of illustration is that it signifies in relation to the written word; illustrations are not secondary supplements, but they are interpretive. ${ }^{21} \mathrm{It}$ is sometimes assumed that illustrations necessarily support the words on the page, or that - to put it another way - image and text consistently align. Illustrations and written word certainly may closely cohere, but even when there is an effective collaboration between author and artist the relationship is dialogic. In Missionary Travels, Livingstone's written account of the reception and its illustration in engraving diverge in several respects. The narrative pays attention to the clothing worn by the Shinde, by Sambanza (a Lunda representative who introduced Livingstone to the court), and by the women present in the assembly, so that the cumulative effect is an occasion of stately grandeur. Shinde, writes Livingstone, was seated:

on a sort of throne covered with a leopard's skin. He had on a checked jacket, and a kilt of scarlet baize edged with green; many strings of large beads hung from his neck, and his limbs 
were covered with iron and copper armlets and bracelets; on his head he wore a helmet made of beads woven neatly together, and crowned with a great bunch of goose-feathers. ${ }^{22}$ In the engraving, by contrast, there is no sign of any "checked jacket" but, like all Africans in attendance, the Shinde is bare chested. His lower garment, meanwhile, is much less a "kilt of scarlet baize edged with green" than a loin cloth of the sort readily found in nineteenth-century sketches of African peoples. The Shinde's ceremonious attire is downgraded overall into a more minimal costume. The same result is detectable in Sambanza, husband of the Lunda chief Manenko who was also the Shinde's niece; as the individual responsible for announcing the Makololo party, Sambanza must be identified with the figure holding a shield, arm aloft, situated between Livingstone and the Shinde. In the text, Livingstone reports that Sambanza appeared "gayly attired, and, besides a profusion of beads, had a cloth so long that a boy carried it after him as a train", but the illustration portrays him wearing only a simple knee-length garment. ${ }^{23}$ This reduction of opulence is repeated in the representation of the Lunda women, clustered to the Shinde's right; their almost nude appearance contrasts conspicuously with Livingstone's description, in which they are "clothed in their best, which happened to be a profusion of red baize".${ }^{24}$ The translation of the scene from text to engraving, then, was one of diminishment. While some of the illustration's limitations - like the reduced size of the kotla (reportedly "about a hundred yards square") and the reduced number of attendees (reportedly around "a thousand people") - are surely due to the technical difficulty of capturing such detail in engraving, this explanation does not readily account for the reductive depiction of Lunda dress. ${ }^{25}$ Rather, the engraving reveals what Christopher Steiner calls the "conventionalizing" pattern of travel illustration, in which artists relied on "conventional canons of composition to represent the non-European subjects they had not seen". ${ }^{26}$ Despite the details provided in Livingstone's narrative, the artist's reliance on scanty garments and exposed body parts ensured that the illustration conformed to familiar visual signifiers of the primitive and exotic. As the following section will elaborate, Livingstone was attune to the considerable impact of visual 
material, and was concerned that graphics - produced by individuals who had not been part of the expedition - might distort the scenes they represented.

\section{Reading Illustrations through the Archive: An Author's Demands}

Tensions between textual and visual representation invite the researcher to take a closer look at the processes underlying the production of illustrative material. It is crucial to recognise that the illustration on the page is the end product of a process involving multiple agents, including author, publisher, artist and engraver. In certain cases, the researcher can go behind the image and disclose the exchanges involved in this fundamentally collaborative facet of book production. Investigating illustrations in this manner extends the analysis so far by following the practices of book historians, who address questions pertaining to publishing by tracing the "material evidence of print culture" through the archive. ${ }^{27}$ The researcher interested in undertaking a book-historical approach - or examining a book as a material artefact - should consider the sources of information that are available; a collection of publisher's papers is often the key depository of documents, including financial records, correspondence, and draft material. Such documentation will not always be extant, but a tool like JISC's Archives Hub, which allows online searches across UK archival holdings, can assist in ascertaining if there are relevant papers to consult.

In the case of Missionary Travels, the book-historical approach is facilitated by the John Murray Archive in the National Library of Scotland. This archive has also been digitized by Adam Matthew as the Nineteenth Century Literary Society project, while the records relating to Livingstone's book are curated in Livingstone's Missionary Travels Manuscript, an open-access digital edition published by Livingstone Online. Since the Murray collection and the wider Livingstone manuscript record are particularly extensive and well-preserved, equally rich materials cannot be expected for every subject, but the following analysis illustrates the avenues that researchers might pursue when there is a substantial archival holding. In the first instance, the financial ledgers of the Murray publishing house provide detailed accounts of the personnel and specific costs involved in 
the production of the firm's numerous publications. ${ }^{28}$ The records for Missionary Travels indicate that the major investment was the two intricate maps prepared by John Arrowsmith, which cost the publisher a substantial $£ 515 / 13 / 6$. Engraving, however, was also a considerable outlay. William Holl was commissioned to engrave Livingstone's portrait for the sum of $f 60 / 18$, but the majority of the work fell to Josiah Whymper who was paid $£ 242 / 12$ for the labour. Subjects engraved on wood were often based on prior drawings, sometimes produced by the explorer or by another artist. As the ledger indicates, Murray employed the successful wildlife artist, Joseph Wolf, for $£ 75 / 1 / 6$ to provide Livingstone with artwork. ${ }^{29}$ According to the firm's daybook, which records day-to-day transactions, Wolf completed twelve drawings for the travelogue as well as five preliminary sketches. ${ }^{30}$ It might readily be assumed that "Reception of the Mission by Shinté", which was clearly composed on the basis of Livingstone's description, was Wolf's handiwork. However, further investigation indicates this is not the case, for the illustration does not appear in the list of twelve illustrations for Missionary Travels compiled by Wolf's biographer. ${ }^{31}$ The artist responsible for the scene remains uncertain, but the ledger gives a clue; since the engraver Josiah Whymper - himself an accomplished draughtsman - is listed as a payee for both "Drawg [drawing] \& Engg [engraving]", it is probable that the composition was his own original. ${ }^{32}$

The circumstances surrounding the production of the "Reception" are extended by other archival records. In fact, the source image for the present case study is a proof engraving provided to the author for his assessment prior to publication. As such, the image is itself a repository of information about the illustrative process; it is heavily marked up, surrounded by comments in two identifiable hands - the black ink of the publisher, John Murray, and Livingstone's own pencil script. At the top of the proof, Livingstone has added remarks that express his dissatisfaction on a range of counts. "Could the artist", he writes, "not make the sheaves of arrows on the boys shoulder as a soldier carries his musket \& not on their backs? Many more rings on the legs \& arms of Shinte would be an improvement $\& \wedge$ plenty of beads round the necks of the women”. Such annotations highlight 
Livingstone's active involvement in the illustrative process and his eagerness to exert influence over the visual representation of narrative events. More specifically, his attention to the appearance of the subjects - the Shinde, the boys on his right and the women on his left - reveals a desire to ensure verisimilitude and a concern that the engraving did not adequately align with his textual description. This is clarified on consulting the body of correspondence between author and publisher. In a letter to Murray Livingstone elaborated on his request, noting that rings "up to the knees \& on the arms" on the Shinde were important because the narrative described "the gait of the Balonda gentlemen as regulated by the weight either real or supposed of these ornaments". ${ }^{33}$ Although, as Koivunen points out, these demands were fairly minimal and would make little substantive impact on the illustration's overall effect, Livingstone was trying to bring the image into closer alignment with his written representation of the reception. ${ }^{34}$

In fact, the archival trail discloses that the comments on the proof were not Livingstone's first criticisms of this illustration. On $22^{\text {nd }}$ May 1857, Livingstone wrote to Murray to confirm receipt of the "proofs of the plates" and to lodge a variety of objections. "The reception at Shinté's which came to day is very poor", he complained, so he had "made some notes for the artist". The "notes" that follow, however, suggest that Livingstone was at this stage viewing an earlier proof. "My men ought to be close to me", he wrote, while the artist should add "Two ficus or banian trees" and make the "roofs of the huts seen over the walls on one side as I have indicated"..$^{35}$ Given that the markedup engraving bears no annotations relating to these complaints - and clearly shows trees flanking the courtyard with roofs in eyeline beyond the wall - the requested changes must have been implemented earlier in the illustration process. When Livingstone asked for additional beads to be placed on the Shinde and the seated women, he was actually seeking improvements to an illustration that had already been subject to considerable revision; he had previously intervened in the illustrative process with major requests that aimed to conform the engraving to the written text. The illustration, as I have suggested, ultimately conventionalises the intercultural meeting between 
Livingstone's party and the Shinde. But Livingstone's two phases of commentary combine to work against the logic of conventionalisation, by encouraging the engraver to introduce more specificity into the scene. Since the illustration was designed to represent an important political moment in his cross-continent journey, Livingstone could have been concerned that it would diminish the scale and significance of the encounter. His later requests may have been minor, but they were in any case part of an effort to generate particularity in an illustration that was staging the "reception" in a generalising mode.

\section{Reading Illustrations through the Archive: A Publisher's Response}

Previous scholarship on Missionary Travels has thoroughly documented the difficult working relationship between Livingstone and the artist, Joseph Wolf. ${ }^{36}$ Livingstone complained about the shortcomings of the artist's work - particularly the "absolutely abominable" depiction of "The Missionary's Escape from the Lion" - while Wolf would later disparage Livingstone's inadequate powers of "vivid verbal description" ${ }^{37}$ As this case study clarifies, moreover, Livingstone's complaints about illustrations did not only revolve around one individual's artwork. He not only aired grievances about Wolf, but also about Whymper; likewise, he even excoriated the shortcomings of the portrait by Henry Philips. ${ }^{38}$ Such a pattern of objections highlights just how exacting an author Livingstone proved to be, and underscores his concern to retain representational control as his narrative was prepared for print. The question remains, however: how did the publishing house deal with Livingstone's repeated requests for amendments?

The particular case of the "Reception" indicates that John Murray was quite willing to accommodate one of his prized authors. In the left-hand margin of the proof, Murray instructs the engraver to comply with at least some of Livingstone's latest demands: "Mr Whymper please place more rings on the chiefs arms \& legs". Comparison between the proof and the final engraving provides further clarity, by confirming that this request was indeed implemented; in the published 
version, moreover, the boys' arrows now rest across their bodies as Livingstone instructed, while strings of beads are faintly detectable around the necks of the women. Following the usual midnineteenth-century practice, the illustrations for Missionary Travels were created using wood engraving, a technique that involved applying cutting tools to a hardwood block to produce a raised design; the raised (or relief) surface took the ink and thereby formed a printable - and mass reproducible - image. ${ }^{39}$ Once an engraving had been prepared, minor amendments of the sort described above could be introduced without much complication. Major alterations, on the other hand, were more time-consuming and difficult to accomplish. ${ }^{40}$ Adding substantial features like the two trees or multiple roofs, which Livingstone had requested earlier, would have required the partial - or complete - replacement of the original block and considerable re-engraving. As Withers, Keighren and Bell note, "the house of Murray endeavoured to respect its authors' wishes" when it came to paratextual matters like illustration, but "the final decision on the presentation of their literary property was more often than not the publisher's prerogative" ${ }^{41}$ The extent to which Murray complied with Livingstone's demands - initially for major modification and subsequently for further correction - is accordingly striking; the considerable financial outlay was presumably deemed worthwhile in the case of a potential bestseller.

Yet, although Murray showed considerable flexibility it is not the case that all of Livingstone's demands were simply granted. Rather, correspondence about the "Reception" reveals that some of his recommendations were sidelined. Livingstone's request for the musician's drum to be "slung on the neck \& beaten with the hands" was never addressed, and his feedback on the marimba's design was probably also ignored, for he was dissatisfied enough with the final engraving to send a sketch of the instrument for inclusion as a separate illustration. ${ }^{42}$ The implementation of some changes and not others indicates that illustration should be regarded as a transactional process. Indeed, the exchanges around illustrative material bring into focus the wider dynamics of book production, in which tensions between parties - on matters ranging from advertising and retail 
cost, to content and literary style - were a regular feature. The publication of Missionary Travels, like many other works of geographical travel, involved negotiations that resulted in compromise on both sides of the author-publisher partnership. ${ }^{43}$

\section{Conclusion}

This case study has developed an approach for the research and analysis of illustrations in published media. First, it modelled contextualisation by showing how researchers might examine the wider function of illustrations in a particular genre and their specific function in a particular text. Second, it demonstrated how illustrations can be analysed both as artefacts in themselves and as artistic objects than signify in interaction with words on the page. Finally, the case study implemented bookhistorical methods to show how following images through the archive can disclose the complexities of the illustrative process. This piece has focused on an engraving from a nineteenth-century expeditionary narrative, but its approach could be applied to illustrations in other print forms and from other historical periods.

\section{Post-evaluation questions}

These are further questions one may ask having critically evaluated the source. 
1. Are there any sources of information not drawn on in this case study that could lend additional insights into this engraving?

2. What other ways could this engraving be interpreted? Does the illustration have any further significance or other possible meanings that have not been explored here?

3. How effectively can other illustrations in Missionary Travels be analysed by following the methods used in this case study? Would any different methods be required?

4. To what extent do you think Livingstone's attempt to control the visual material in Missionary Travels is characteristic of nineteenth-century authors? Or are Livingstone's interactions with his publisher and the artist-engraver unusual?

\section{Next research steps}

These are questions or discussion points one may ask/raise when thinking about next research steps.

1. Does this illustration - or any other in Missionary Travels - have an afterlife? Has it been used in any other publications or formats? If so, does it gain new meanings in these contexts? Has the scene been illustrated differently in any other sources?

2. What other illustrated narratives of expeditionary travel in Africa can you identify for further research? To what extent do they use similar strategies of representation to depict intercultural encounters? What other kinds of illustrations do these texts include, and what are their purposes?

3. Does the John Murray publishing archive provide further insights into the process of illustrating nineteenth-century literature? Are there are any other physical or electronic archives that could extend research in this area? 
1.

\section{Further resources}

- Goldman, Paul, and Simon Cooke (eds). Reading Victorian Illustration, 1855-1875. Farnham:

Ashgate, 2012. 
- Keighren, Innes M., Charles W. J. Withers, and Bill Bell. Travels into Print: Exploration, Writing, and Publishing with John Murray, 1773-1859. Chicago: University of Chicago Press, 2015.

- Koivunen, Leila. Visualizing Africa in Nineteenth-Century British Travel Accounts. New York: Routledge, 2009.

- $\quad$ Livingstone, Justin D. “Composing \& Publishing Missionary Travels." On Livingstone's Missionary Travels Manuscript, directed by Justin D. Livingstone and Adrian S. Wisnicki. In Livingstone Online, directed by Adrian S. Wisnicki and Megan Ward, 2019.

https://livingstoneonline.org/in-his-own-words/missionary-travels-manuscript/livingstones$\underline{\text { missionary-travels-manuscript-1857 }}$

- Maxwell, Richard (ed). The Victorian Illustrated Book. Charlottesville: University Press of Virginia, 2002.

- $\quad$ Miller, J. Hillis. Illustration. London: Reaktion Books, 1992.

- Thomas, Julia. Pictorial Victorians: The Inscription of Values in Word and Image. Athens: Ohio University Press, 2004. 


\section{Endnotes}

\footnotetext{
1 Julia Thomas, "Illustrations and the Victorian Novel", in The Oxford Handbook of Victorian Literary Culture, ed. Juliet John (Oxford: Oxford University Press, 2016), 621.

${ }^{2}$ See, for example, Leila Koivunen, Visualizing Africa in Nineteenth-Century British Travel Accounts (New York: Routledge, 2009).

${ }^{3}$ David Livingstone, Missionary Travels and Researches in South Africa (London: John Murray, 1857), opposite 291.
}

${ }^{4}$ Innes M. Keighren, Charles W. J. Withers, and Bill Bell, Travels into Print: Exploration, Writing, and Publishing with John Murray, 1773-1859 (Chicago: University of Chicago Press, 2015), 4-5.

${ }^{5}$ Koivunen, Visualizing Africa, 3, 157.

${ }^{6}$ Felix Driver, "Missionary Travels: Livingstone, Africa and the Book," in "Livingstone Studies: Bicentenary Essays," ed. Justin D. Livingstone, special issue, Scottish Geographical Journal 129, no. 3-4 (2013): 166.

${ }^{7}$ Koivunen, Visualizing Africa, 3.

${ }^{8}$ Tim Barringer, “Fabricating Africa: Livingstone and the Visual Image 1850-74," in David Livingstone and the Victorian Encounter with Africa, ed. John M. MacKenzie (London: National Portrait Gallery, 1996), 171.

9 James Clifford, "Introduction: Partial Truths," in Writing Culture: The Poetics and Politics of Ethnography, ed. James Clifford and George E. Marcus (Berkeley: University of California Press, 1986), 2. Qtd. in Barringer, "Fabricating Africa", 171.

${ }^{10}$ Keighren, Withers, and Bell, Travels into Print, 174.

${ }^{11}$ Isaac Schapera (ed), Livingstone's African Journal, 1853-1856, vol. 1 (London: Chatto \& Windus, 1963), 38.

12 Livingstone, Missionary Travels, 227.

${ }^{13}$ Walima T. Kalusa, “Elders, Young Men, and David Livingstone's 'Civilising Mission': Revisiting the Disintegration of the Kololo Kingdom, 1851-1864," The International Journal of African Historical Studies 42, no. 1 (2009): 60-61, 70.

${ }^{14}$ Livingstone, Missionary Travels, 281-94.

${ }^{15}$ Livingstone, Missionary Travels, 301-02.

${ }^{16}$ Mary Borgo Ton, "The Ishinde", in "Shining Lights: Magic Lanterns and the Missionary Movement, 18391868" (PhD thesis, Indiana University, 2019). http://scalar.maryborgoton.com/shininglights/index.

17 Julia Thomas, Nineteenth-Century Illustration and the Digital: Studies in Word and Image (Cham: Palgrave Macmillan, 2017), 6. Thomas, "Illustrations", 621.

18 Livingstone, Missionary Travels, 228.

${ }^{19}$ Felix Driver and Lowri Jones, Hidden Histories of Exploration (London: Royal Holloway, University of London, 2009), 5, 11; Kennedy, Last Blank Spaces, 236.

${ }^{20}$ Andrew Ross, David Livingstone: Mission and Empire (London: Hambledon and London, 2002), 94.

21 Thomas, "Illustrations," 632.

22 Livingstone, Missionary Travels, 291.

${ }^{23}$ Livingstone, Missionary Travels, 292.

${ }^{24}$ Livingstone, Missionary Travels, 292.

${ }^{25}$ Livingstone, Missionary Travels, 291, 294.

${ }^{26}$ Christopher B. Steiner, "Travel Engravings and the Construction of the Primitive", in Prehistories of the Future: The Primitivist Project and the Culture of Modernism, ed. Elazar Barkan and Ronald Bush (Stanford: Stanford University Press, 1995), 207-8.

${ }^{27}$ Katherine Bode and Roger Osborne, "Book History from the Archival Record," in The Cambridge Companion to the History of the Book, ed. Leslie Howsam (Cambridge: Cambridge University Press, 2015), 219.

${ }^{28}$ See the relevant financial records here: https://livingstoneonline.org/in-his-ownwords/catalogue?query=Murray\&f\%5B0\%5D=dateRangeYear mi\%3A\%5B1857\%20TO\%201861\%5D\&f\%5B1\%5 $\mathrm{D}=$ genre ms\%3A\%22account\%20books\%22

${ }^{29}$ Copies Ledger E of the Publisher John Murray, 1857-62, MS. 42730, 422, National Library of Scotland, Edinburgh.

${ }^{30}$ Copies Daybook of the Publisher John Murray, 1853-1857, MS 42899, 383, National Library of Scotland, Edinburgh. 
${ }^{31}$ Alfred Herbert Palmer, The Life of Joseph Wolf (London: Longmans, Green \& Co., 1895), 123.

${ }^{32}$ Copies Ledger E.

${ }^{33}$ David Livingstone, Letter to John Murray III, 24 May-27 Aug 1857, MS. 42420, National Library of Scotland, Edinburgh, Scotland.

${ }^{34}$ Leila Koivunen, "Africa on the Spot and from the Distance: David Livingstone's Missionary Travels and Nineteenth-Century Practices of Illustration", in "Livingstone Studies: Bicentenary Essays," ed. Justin D. Livingstone, special issue, Scottish Geographical Journal 129, no. 3-4 (2013): 203.

${ }^{35}$ David Livingstone, Letter to John Murray III, 22 May 1857, MS. 42420, National Library of Scotland, Edinburgh, Scotland.

${ }^{36}$ Leila Koivunen, "Visualising Africa - Complexities of Illustrating David Livingstone's Missionary Travels," Ennen \& Nyt 1 no. 6 (2001): 6; Koivunen, "Africa on the Spot," 202; Louise Henderson, "Publishing Livingstone's Missionary Travels," in Livingstone Online, dirs. Adrian S. Wisnicki and Megan Ward, 2015. https://livingstoneonline.org/life-and-times/publishing-livingstones-missionary-travels.

37 Palmer, Joseph Wolf, 123.

${ }^{38}$ David Livingstone, Letter to John Murray III, 12 Nov. 1857, MS. 42420, National Library of Scotland, Edinburgh, Scotland.

${ }^{39}$ Koivunen, Visualizing, 157.

${ }^{40}$ Koivunen, Visualizing, 167.

${ }^{41}$ Keighren, Withers, and Bell, Travels into Print, 174.

${ }^{42}$ Livingstone, Letter to John Murray III, 22 May 1857; Livingstone, Letter to John Murray III, 24 May-27 Aug 1857.

${ }^{43}$ Henderson, "Publishing"; Justin D. Livingstone, Livingstone's "Lives": A Metabiography of a Victorian Icon (Manchester: Manchester University Press, 2014), 26-41; Justin D. Livingstone, "Composing \& Publishing Missionary Travels", in Livingstone's Missionary Travels Manuscript, dirs. Justin D. Livingstone and Adrian S. Wisnicki, in Livingstone Online, dirs. Adrian S. Wisnicki and Megan Ward, 2019.

\section{References}

Barringer, Tim. "Fabricating Africa: Livingstone and the Visual Image 1850-74." In David Livingstone and the Victorian Encounter with Africa, edited by John M. MacKenzie, 170-97. London: National Portrait Gallery, 1996.

Bode, Katherine, and Roger Osborne. "Book History from the Archival Record." In The Cambridge Companion to the History of the Book, edited by Leslie Howsam, 219-35. Cambridge: Cambridge University Press, 2015.

Borgo Ton, Mary. "The Ishinde." In "Shining Lights: Magic Lanterns and the Missionary Movement, 1839-1868." PhD thesis, Indiana University, 2019.

http://scalar.maryborgoton.com/shininglights/index

Clifford, James. "Introduction: Partial Truths." In Writing Culture: The Poetics and Politics of Ethnography, edited by James Clifford and George E. Marcus, 1-26. Berkeley: University of California Press, 1986. 
Copies Daybook of the Publisher John Murray. 1853-1857. MS 42899, 383, National Library of Scotland, Edinburgh.

Copies Ledger E of the Publisher John Murray. 1857-62. MS. 42730, 422. National Library of Scotland, Edinburgh.

Driver, Felix, and Lowri Jones. Hidden Histories of Exploration. London: Royal Holloway, University of London, 2009.

Driver, Felix. "Missionary Travels: Livingstone, Africa and the Book." In "Livingstone Studies: Bicentenary Essays," edited by Justin D. Livingstone, special issue, Scottish Geographical Journal 129, no. 3-4 (2013): 164-78.

Henderson, Louise. "Publishing Livingstone's Missionary Travels." In Livingstone Online, directed by Adrian S. Wisnicki and Megan Ward, 2015. https://livingstoneonline.org/life-andtimes/publishing-livingstones-missionary-travels.

Kalusa, Walima T. “Elders, Young Men, and David Livingstone's 'Civilising Mission': Revisiting the Disintegration of the Kololo Kingdom, 1851-1864." The International Journal of African Historical Studies 42, no. 1 (2009): 55-80.

Keighren, Innes M., Charles W. J. Withers, and Bill Bell. Travels into Print: Exploration, Writing, and Publishing with John Murray, 1773-1859. Chicago: University of Chicago Press, 2015.

Kennedy, Dane. The Last Blank Spaces: Exploring Africa and Australia. Cambridge, Massachussets: Harvard University Press, 2013.

Koivunen, Leila. "Africa on the Spot and from the Distance: David Livingstone's Missionary Travels and Nineteenth-Century Practices of Illustration." In "Livingstone Studies: Bicentenary Essays," edited Justin D. Livingstone, special issue, Scottish Geographical Journal 129, no. 3-4 (2013): 194-209. 
Koivunen, Leila. “Visualising Africa - Complexities of Illustrating David Livingstone's Missionary Travels." Ennen \& Nyt 1 no. 6 (2001): 1-12.

Koivunen, Leila. Visualizing Africa in Nineteenth-Century British Travel Accounts. New York: Routledge, 2009).

Livingstone, David. Letter to John Murray III. 12 Nov. 1857. MS. 42420, National Library of Scotland, Edinburgh, Scotland.

Livingstone, David. Letter to John Murray III. 22 May 1857. MS. 42420. National Library of Scotland, Edinburgh, Scotland.

Livingstone, David. Letter to John Murray III. 24 May-27 Aug 1857. MS. 42420. National Library of Scotland, Edinburgh, Scotland.

Livingstone, David. Missionary Travels and Researches in South Africa. London: John Murray, 1857.

Livingstone, Justin D. “Composing \& Publishing Missionary Travels." On Livingstone's Missionary Travels Manuscript, directed by Justin D. Livingstone and Adrian S. Wisnicki. In Livingstone Online, directed by Adrian S. Wisnicki and Megan Ward, 2019. https://livingstoneonline.org/inhis-own-words/missionary-travels-manuscript/livingstones-missionary-travels-manuscript-1857

Livingstone, Justin D. Livingstone's "Lives": A Metabiography of a Victorian Icon. Manchester: Manchester University Press, 2014.

Palmer, Alfred Herbert. The Life of Joseph Woolf. London: Longmans, Green \& Co., 1895.

Ross, Andrew. David Livingstone: Mission and Empire. London: Hambledon and London, 2002. Schapera, Isaac (ed). Livingstone's African Journal, 1853-1856, vol. 1. London: Chatto \& Windus, 1963. 
Steiner, Christopher B. "Travel Engravings and the Construction of the Primitive." In Prehistories of the Future: The Primitivist Project and the Culture of Modernism, edited by Elazar Barkan and Ronald Bush, 202-25. Stanford: Stanford University Press, 1995.

Thomas, Julia. "Illustrations and the Victorian Novel." In The Oxford Handbook of Victorian Literary Culture, edited by Juliet John, 617-36 (Oxford: Oxford University Press, 2016).

Thomas, Julia. Nineteenth-Century Illustration and the Digital: Studies in Word and Image. Cham: Palgrave Macmillan, 2017.

- Note: SAGE will not accept cases that are incorrectly referenced; please ensure accuracy before submission. For help on reference style See here for guidance on Chicago Manual of Style. 